Environment Conservation Journal 14(1\&2) 65-68 , 2013

ISSN 0972-3099 (Print) 2278-5124 (Online)

Abstracted and Indexed

\title{
Length-weight relationship and ponder index of two Indian major carps in Dejla Dewada reservoir, Khargone, M.P.
}

\author{
S.K.Pathak $\varpi^{1}$ and Sandhya Kshetre ${ }^{2}$
}

Received: 28.12.2012

Revised: 26.03 .2013

Accepted: 8.04.2013

\begin{abstract}
The total 200 specimens of Catla catla and Cirrhinus mrigla were worked out during the two year study periods, from Dejla Dewada reservoir of Khargone district. Total length and body weight were estimated. The correlation coefficient (" $r$ ") and ponder index ("Kn") have also been computed. The result showed the growth of two IMC is satisfactory. The value of exponent ' $n$ ' in the equation $W=c L^{n}$ were 1.9416 and 1.4798 for Catla catla and Cirrhinus mrigla. The relative condition factor ("Kn") remained greater than one fir both IMC indicating their good well being.
\end{abstract}

Keywords Length-weight relationship, Indian major carp, cube law, Ponder index

\section{Introduction}

The study of the length -weight relationship of fishes is of vital importance to the fishery biologists. The application of our knowledge with context of fishery biology will help in detecting suitable and fertile fishing water body and to increase the fish production in our country. The environmental factors and the availability of fish food also effects this relationship. The lengthweight relationship shows economic value of fish.

The length -weight relationship of the Indian major carps expressed by the equation: $\mathrm{W}=\mathrm{CL}^{\mathrm{n}}$. Several workers viz. Jhingran $(1959,68)$, Sinha (1972), Pathak(1975), Soni and Kathal(1979), Quadri and Mir(1980), Srivastava and Pandey (1981), Prakash and Rawat(1990), Adholia(1990), Das Gupta (1990),Shrivastava and Desai (1993),Patgiri et al.(2001), Saroja et al. (2002)Pathak (2005),Dagonkar and Prakash(2009) have been reported from various water bodies in India. The available literature in this context in M.P. is very meager, therefore the present study was planned. The investigation describes the length -weight relationship in two economically important fishes viz Catla catla and Cirrhinus mrigla collected from Dejla Dewada reservoir.

\section{Author's Address}

${ }^{1}$ P.G. Department of Zoology, B.L.P.Govt P.G. College, Mhow

${ }^{2}$ P.G. Department of Zoology, Govt P.G. College, Khargone

E-mail:skpathak57@gmail.com

\section{Material and Methods}

After the collection of fishes from Dejla Dewada reservoir and local market preserved in 5\% formaline and were analysed for its length -weight relationship. The total length of both major carps were measured on the measuring board. The preserved fishes were weighed on a platform balance. The data of L-W relationship and their log values $K_{n}$ etc. have been shown in the table.

The L-W relationship was calculated according to formula:-

$$
\mathrm{W}=\mathrm{CL}^{\mathrm{n}}
$$

Where, $\mathrm{W}$ represents the weight of fish, $\mathrm{L}$ its length and $\mathrm{c}$ and $\mathrm{n}$ are constants. A logarithmic transformation of the formula given a straight line relationship of the term as -

$$
\text { Log } W=\log c+n . \log L
$$

The ponderal index $(\mathrm{Kn})$ was calculated by the formula:-

$$
\text { Ponderal index }(\mathrm{Kn})=\frac{\text { Wt. in gr. X } 100}{-----------}
$$

\section{Results and discussion}

The regression equations in the logarithmic form of Catla catla and Cirrhinus mrigla were found be $\log \mathrm{W}=0.00145+1.9416$ and $\log \mathrm{W}=0.00329$ +1.4798 respectively (Table- 1 ). 
Table 1: Length weight relationship of Cirrhinus mrigala

\begin{tabular}{|c|c|c|c|c|c|c|c|c|c|c|c|c|c|}
\hline $\begin{array}{c}\text { S.NO } \\
.\end{array}$ & $\begin{array}{c}\text { No. } \\
\text { of } \\
\text { Fishes }\end{array}$ & $\begin{array}{c}\text { Average } \\
\text { length in } \\
\text { in } \mathrm{cm} . \\
\text { (L) }\end{array}$ & $\log L$ & $\begin{array}{c}\text { Average } \\
\text { observed } \\
\text { Wt. in gm } \\
\text { (W) }\end{array}$ & $\begin{array}{l}\text { Observe } \\
\text { d LogW }\end{array}$ & $\begin{array}{l}\log L X \\
\log w\end{array}$ & $(\log L)^{2}$ & $\begin{array}{c}(\log W \\
)^{2}\end{array}$ & $\begin{array}{l}\text { Calculat } \\
\text { e } \quad \log a\end{array}$ & $\begin{array}{l}\text { Calculat } \\
\text { e } \log n\end{array}$ & $\begin{array}{l}\text { Calculat } \\
\text { e Log W }\end{array}$ & $\begin{array}{c}\text { Calculat } \\
\text { e Wt. In } \\
\text { gm. }\end{array}$ & $\begin{array}{c}\text { Ponderal } \\
\text { index }\end{array}$ \\
\hline 1 & 12 & 8.8 & 1.0253 & 18 & 0.8854 & 0.8362 & 0.892 & 0.7839 & 0.003296 & 1.47978 & 1.4009 & 25.1725 & 1.1269 \\
\hline 2 & 11 & 10.6 & 1.1239 & 22.3 & 1.2553 & 1.287 & 1.0512 & 1.5757 & 0.003296 & 1.47978 & 1.5205 & 33.1534 & 1.5113 \\
\hline 3 & 15 & 13.3 & 1.2014 & 25.8 & 1.3483 & 1.5153 & 1.263 & 1.8179 & 0.003296 & 1.47978 & 1.6663 & 46.3825 & 0.9479 \\
\hline 4 & 18 & 15.9 & 1.3054 & 67.7 & 1.4116 & 1.6959 & 1.4433 & 1.9927 & 0.003296 & 1.47978 & 1.7811 & 60.4094 & 0.6418 \\
\hline 5 & 16 & 20.2 & 1.3945 & 101.3 & 1.8306 & 2.3895 & 1.7039 & 3.3511 & 0.003296 & 1.47978 & 1.9349 & 86.0864 & 0.8213 \\
\hline 6 & 16 & 24.8 & 1.4609 & 286 & 2.0057 & 2.7967 & 1.9445 & 4.0224 & 0.003296 & 1.47978 & 2.0668 & $116 . .6229$ & 0.6641 \\
\hline 7 & 18 & 28.9 & 1.4712 & 362 & 2.4564 & 3.5884 & 2.1342 & 6.0337 & 0.003296 & 1.47978 & 2.1651 & 146.2545 & 1.1849 \\
\hline 8 & 17 & 29.6 & 1.5092 & 421.6 & 2.5587 & 3.7646 & 2.1647 & 6.5469 & 0.003296 & 1.47978 & 2.1804 & 151.5271 & 1.3959 \\
\hline 9 & 20 & 32.3 & 1.5671 & 527.2 & 2.6249 & 3.9615 & 2.2777 & 6.8901 & 0.003296 & 1.47978 & 2.2366 & 172.421 & 1.2511 \\
\hline 10 & 20 & 36.9 & 1.6365 & 670.2 & 2.7219 & 4.2654 & 2.4556 & 7.4091 & 0.003296 & 1.47978 & 2.3221 & 209.9699 & 1.0493 \\
\hline 11 & 17 & 43.3 & 1.6981 & 814.3 & 2.8262 & 4.6251 & 2.6781 & 7.9874 & 0.003296 & 1.47978 & 2.4249 & 266.0389 & 0.8313 \\
\hline 12 & 20 & 49.9 & 16.3378 & & 2.9108 & 4.9428 & 2.8835 & 8.4727 & 0.003296 & 1.47978 & 2.5161 & 328.1849 & 0.6554 \\
\hline \multirow[t]{2}{*}{$\Sigma=$} & $\Sigma=200$ & $\Sigma L=314.5$ & $\sum \log \mathrm{L}=$ & $\Sigma W=$ & $\Sigma \log W=$ & $\sum \log \mathrm{LXW}$ & $\sum \log \mathrm{L}^{2=}$ & $\Sigma \log \mathrm{W}^{2=}$ & & & & & \\
\hline & & & 16.3378 & 3324.14 & 24.8357 & 35.6686 & 22.8919 & 56.8838 & & & & & \\
\hline
\end{tabular}

Table 1: Length weight relationship of Catla catla

\begin{tabular}{|c|c|c|c|c|c|c|c|c|c|c|c|c|c|}
\hline S.NO. & $\begin{array}{l}\text { No. of } \\
\text { Fishes }\end{array}$ & $\begin{array}{l}\text { Average } \\
\text { length in } \\
\text { in } \mathrm{cm} . \\
\text { (L) }\end{array}$ & $\log L$ & $\begin{array}{l}\text { Average } \\
\text { observed } \\
\text { Wt. in gm } \\
\text { (W) } \\
\end{array}$ & $\begin{array}{l}\text { Observed } \\
\text { LogW }\end{array}$ & $\begin{array}{l}\log L X \\
\log w\end{array}$ & $(\log L)^{2}$ & $(\log W)^{2}$ & $\begin{array}{c}\text { Calculate } \\
\text { Log a }\end{array}$ & $\begin{array}{c}\text { Calculate } \\
\text { Log } n \\
\end{array}$ & $\begin{array}{c}\text { Calculate } \\
\text { Log W }\end{array}$ & \begin{tabular}{|l|} 
Calculate \\
Wt. In gm. \\
\end{tabular} & $\begin{array}{c}\text { Ponderal } \\
\text { index }\end{array}$ \\
\hline 1 & 10 & 8.2 & 0.9138 & 0.9138 & 1.2922 & 1.2922 & 0.835 & 1.6698 & 0.001396 & 1.94211 & 1.7761 & 59.7207 & 3.55479 \\
\hline 2 & 15 & 15.2 & 1.1818 & 1.1818 & 2.1477 & 2.1477 & 1.3967 & 4.6126 & 0.001396 & 1.94211 & 2.2967 & 198.0613 & 4.0008 \\
\hline 3 & 18 & 24.1 & 1.382 & 1.382 & 2.602 & 2.602 & 1.9101 & 6.7707 & 0.001396 & 1.94211 & 2.6854 & 484.6489 & 2.85765 \\
\hline 4 & 16 & 29.2 & 1.4654 & 1.4654 & 3.0146 & 3.0146 & 2.1473 & 0.0876 & 0.001396 & 1.94211 & 2.8479 & 704.5384 & 4.1539 \\
\hline 5 & 18 & 33.4 & 1.5237 & 1.5237 & 3.1609 & 3.1609 & 2.3218 & 9.9914 & 0.001396 & 1.94211 & 2.9607 & 913.4429 & 3.9842 \\
\hline 6 & 13 & 34.1 & 1.5327 & 1.5327 & 3.179 & 3.179 & 2.3493 & 10.1064 & 0.001396 & 1.94211 & 2.9782 & 950.9896 & 3.8089 \\
\hline 7 & 18 & 45.6 & 1.659 & 1.659 & 3.3181 & 3.3181 & 2.7522 & 11.0114 & 0.001396 & 1.94211 & 3.2233 & 1672.209 & 2.19366 \\
\hline 8 & 16 & 48.2 & 1.683 & 1.683 & 3.3598 & 3.3598 & 2.8326 & 11.2886 & 0.001396 & 1.94211 & 3.2701 & 1862.3481 & 2.04509 \\
\hline 9 & 20 & 56.4 & 1.7513 & 1.7513 & 3.4802 & 3.4802 & 3.067 & 12.1122 & 0.001396 & 1.94211 & 3.4026 & 2526.825 & 1.68433 \\
\hline 10 & 16 & 65.6 & 1.8169 & 1.8169 & 3.5798 & 3.5798 & 3.3011 & 12.815 & 0.001396 & 1.94211 & 3.5301 & 3388.6414 & 1.34612 \\
\hline 11 & 20 & 72.4 & 1.8597 & 1.8597 & 3.6474 & 3.6474 & 3.4586 & 13.335 & 0.001396 & 1.94211 & 3.6132 & 4104.0756 & 1.16995 \\
\hline 12 & 20 & 80.2 & 1.9042 & 1.9042 & 3.7638 & 3.7638 & 3.6259 & 14.1663 & 0.001396 & 1.94211 & 3.6995 & 5006.2738 & 1.12537 \\
\hline & $\theta=200$ & 回 $\mathrm{L}=512.6$ & $\begin{array}{c}1 \\
\mathrm{~L}=18.6737 \\
\end{array}$ & बW $=18.6737$ & $\begin{array}{l}\text { Elog } \mathrm{W}= \\
36.5457\end{array}$ & $\begin{array}{c}\text { ⿶ } \log \mathrm{Lx} \\
\mathrm{L} \operatorname{og} \mathrm{w}=36.5457\end{array}$ & $\begin{array}{c}\text { ]( }(\mathrm{Log} \\
\mathrm{L}) 2= \\
29.9977\end{array}$ & $\begin{array}{c}\mathrm{E}(\log W \\
) 2= \\
116.9355\end{array}$ & & & & & \\
\hline
\end{tabular}

The value of correlation coefficient $(\mathrm{r})=0.98$ of grand average ponderal index (Kn) of Catla catla Catla catla and 0.97 of Cirrhinus mrigla. The when all the 12 groups were taken together and 
computed was found to be3.0492, the highest being 4.1535 of the length $24.10 \mathrm{~cm}$. and lowest being 1.3254 in $80.20 \mathrm{~cm}$. length. The average coefficient of condition (Kn) of Cirrhinus mrigla was found to be 1.0067 (table- ), the lowest being 0.6418 of the $15.90 \mathrm{~cm}$. and the highest being 1.5113 in $10.6 \mathrm{~cm}$. length. The average value of ponderal index $(\mathrm{Kn})$ to be more than one of both IMC. It indicated that, the well being of the fish were found to be good. This acts for better reproduction in a better space to give better spawn. The value of ' $n$ ' was comparatively low of the both IMC viz. Catla catla and Cirrhinus mrigla in this locality. This show these fishes deviates from the general "cube law" and did not hold good in the above cases. The similar observation reported by Jhingran (1968) in Gudusia chapra, Rao and Rao (1972) and Pathak (1975) have also observed the ' $n$ ' value less than three for the fishes of Godavari river and Loni reservoir respectively. Khan(1988) in Labeo calbasu, Adholia (1990) in Labeo rohita and Catla catla. Harish et al. (2006) reported 'n 'value less than three for Rasbora daniconus from Sarvathi reservoir,Karnataka. This deviation in the value of ' $n$ ' may be due to change in the environmental factors, the availability of fish food and difference in condition of fish population.Very high values of coefficient of correlation ( $\mathrm{r}$ ) between $\mathrm{L} \& \mathrm{~W}$ in Catla catla (0.98) and Cirrhinus mrigla (0.97) existed. It means that the total weight of the fish is highly correlative to its total length. This observation of present study were supported by Chacko and Ganapathi (1981), Kartha and Rao (1990) and Pandey (1998). The value of "Kn" more than one in both studied fishes. Nasar (1990) also supported this finding in Heterpneustes fossils (bloch). Therefore a need for study of physicochemical parameters of Dejla Dewada reservoir of Khargone district is unavoidable.

Table 3- Length weight relationship of two spices of Indian Major Carps of Dejla Dewada reservoir, M.P.

\begin{tabular}{|c|c|c|c|c|c|c|c|c|c|}
\hline Family & Species & c & $\mathbf{n}$ & $\mathbf{r}$ & $\begin{array}{l}\text { Mean } \\
\text { L } \\
\text { range } \\
\text { (cm.) }\end{array}$ & $\begin{array}{l}\text { Mean } \\
\text { W } \\
\text { range } \\
\text { (mg.) }\end{array}$ & $\begin{array}{l}\text { Mean } \\
\text { (Kn) }\end{array}$ & $\begin{array}{l}\text { Mean } \\
\text { calculate } \\
\text { d Log W }\end{array}$ & $\begin{array}{l}\text { Mean } \\
\text { calculated } \\
\text { Wt. }\end{array}$ \\
\hline Cyprinidae & $\begin{array}{l}\text { Catla } \\
\text { catla }\end{array}$ & 0.001446 & $\begin{array}{l}1.941 \\
6\end{array}$ & 0.98 & $\begin{array}{l}42.72 \\
(8.20- \\
80.20)\end{array}$ & $\begin{array}{l}2165.84 \\
(19.60- \\
5805.20\end{array}$ & $\begin{array}{l}3.0492 \\
(1.3254 \text { - } \\
4.1535)\end{array}$ & $\begin{array}{l}2.8756 \\
(1.7761- \\
3.6995)\end{array}$ & $\begin{array}{l}1822.6429 \\
(59.7207- \\
5006.2738)\end{array}$ \\
\hline Cyprinidae & $\begin{array}{l}\text { Cirrhinus } \\
\text { mrigla }\end{array}$ & 0.003295 & $\begin{array}{l}1.479 \\
8\end{array}$ & 0.97 & $\begin{array}{l}26.21 \\
(8.80- \\
49.90)\end{array}$ & $\begin{array}{c}277.01 \\
(7.68- \\
814.30)\end{array}$ & $\begin{array}{l}1.0067 \\
(0.6418- \\
1.5113)\end{array}$ & $\begin{array}{l}2.0180 \\
(1.4009- \\
2.5161)\end{array}$ & $\begin{array}{l}136.8519 \\
(25.1725- \\
328.1849)\end{array}$ \\
\hline
\end{tabular}

\section{References}

Adholiya,U.N. 1990. Length weight relationship in few cypriniformes fishes from the river Betwa ,India. MATSYA, 15 \& 16:138-144.

APHA, AWWA and WPCF 1989 . Standard Methods for the Examination of Water and Waste Water. $17^{\text {th }}$ edition, APHA,Inc. New York. P.1268.

Chacko, P.I. and Ganapathi 1951. Bionomics of the Mrigala, Cirrhinus mrigla (Ham.) in south Indian water. Bombay Nat. Hist. Soc., 50(1): 13-19.

Dagonkar,Amita and Prakash,M.M. 2009. Length weight relationship of twofish species in Munjsagar talab,Dhar,M.P. Indian research communication 3(1) 41-42.

Das Gupta, M. 1990. Length weight relationship and Condition of the Mahaseer Tor tor (Hamilton) from Garo Hills, India. Proc. $77^{\text {th }}$ Ind.Sc. Cong. Part III.
Harish, Kumar K.,Kiran, B.R.,Purushotam,R.,Puttaia,E.T. and Manjappa,S. 2006. Length weight relationship of Cyprinid fish Rasbora daniconus 9hamilton-Buchanan) from Sarvathi reservoir, Karnataka.Zoo'Print Journal 12(1):2140-2141

Jhingran, A.G. 1952. General length weight relationship of three major carps of India. Proc. Nisc. India 18 : 449- 455.

Jhingran, A.G. 1968. The length weight relationship and $K$ factor of Gudusia chopra (Ham.) from Ganga river system. Proc. Nat. Acad. Sci. India, 35(b), :249-362.

Khan, M.A. 1988. Biology of Labeo calbasu (Ham.) from Tilaya reservoir, Bihar I ): Length weight relationship, Condition index and feeding habits. Proc.Acad.Sci.India, 58 (B) I 41-47.

Kartha,K.N. and Rao, K.S. 1990. Length-weight and length-maximum girth relationship of Catla catla (Ham.) in commercial landings of Gandhisagar Reservoir.Fish.Techno., 27:155-156. 


\section{Pathak and Kshetre}

Le Cren, E.D. 1951. The length weight relationship and seasonal cycle in gonad weight and condition in the Perch (Perca-fluyia jillis). $\boldsymbol{J}$. Anim. Ecol., 20: 201-219.

Patgiri, A. ,Goswami,M.M. Kar,D. and Barbhuiya,M.H. 2001. Comparative study on length weight relationship and relative condition factors in major and exotic carps in pounds of Guwahati.J.Environ.\&Ecopla.5(1):179-180

Pandey, Anil 1998. Hydrobiological studies on Gambheer dam,Ujjain (M.P.) including up and down stream with special reference to fisheries ,Ph.D. thesis, Vikram University,Ujjain,(M.P.).

Prakash, M.M. and Rawat, H. 1990. Length weight relationship in Oxygaster bacaila (Ham.).J.Inst.Agric.Anim.Sci. 11:127-131.

Pathak,S.C. 1975. Length weight relationship, Condition factor and food study of Labeo calbasu (Himilton) from Soni reservoir (Madhya Pradesh).Journal of Inland fisheries Society of India 8;409-434

Pathak, S.K. 2005. Limnological status of Virla Reservoir, District West Nimar (Kargone) M.P., India ,Ph.D. thesis, Devi Ahilya Vishwavidyalaya, Indore,(M.P.)
Quadri, M.Y. and Mir, S. 1980. Length weight relationship of Oreinus plangiostomus (MCCL), Geobios., 7: 158-159.

Saroja,S.P., Sivakumar,A.A. and Chandran,Rashmi 2002. Studies on length weight relationship and sex ratio in Oreochronis mossambicus.Indian J.Environ \& Ecoplan. 6 (2):251-254.

Shrivastava, N.P.C. and Desai, V.R. 1993. Observation on length weight relative condition and net selectivity of Silonia silondia (Hamilton) from Rihand Reservoir (U.P.).Geobios New Rep., 12(1)26-29.

Sinha, M. 1972. Observation on the biology of Puntius sarana (Hamilton) of Loni reservoir (M.P.).I. Length weight relationship food and Condition factors. J. Inland Fish Soc.India, 4:122-131.

Soni, D.D. and Karthal, K.M. 1979. Length weight relationship in Cirrhinus mrigla (Val) and Cyprinus carpio (Ham.). Matsya.5:69-73.

Srivastava, S. and Pandey, A.K. 1981. Length weight relationship and Condition factor of three Indian major carps in composite fish farming . Matsya . 7: 70-74 